\title{
Transformation and Development of Accounting Education Based on Supply-side Reform
}

\author{
Gao Qiaoli \\ Shaanxi Technical College of Finance and Economics, Shaanxi, China, 712000
}

Keywords: attack side reform; accounting education; transformation; development

\begin{abstract}
The transformation of accounting education under the structural reform of supply side is the transformation from financial accounting to management accounting, which helps supply side realize the reform goal of "three go, one fall and one subsidy". In view of the present situation of the teaching of financial accounting specialty and the teaching of management accounting course, countermeasures and suggestions are put forward for the transformation and development of accounting education: changing concepts, establishing the concept of "value added"; constructing a perfect curriculum system of management accounting; perfecting the practical links of training the application ability of management accounting; and putting forward higher requirements for the educators of management accounting through the reform of "supply side"; improving the evaluation system of management accounting professionals.
\end{abstract}

In the process of our country's sustainable economic development, the supply-side reform has injected new vitality into the current stage of economic development. The supply-side reform can optimize the current economic structure, improve the allocation of various elements, and lay the foundation for sustainable economic development. Under this background, it undoubtedly brings certain influence to the development of accounting profession. If the accounting profession wants to develop continuously, it must reform and transform based on the demand of supply-side reform.

\section{Demand and Challenge of Accounting Professional Development Transition from the Perspective of Supply Side}

\subsection{Transforming demand of accounting professional development from the perspective of supply side}

Supply-side reform mainly emphasizes the adjustment of production structure and mode, the promotion of overall productivity, the protection of market freedom, and the rational allocation of resources. From the perspective of supply side, enterprises should systematically re-estimate and analyze their own operating ability and the way to make profits, which requires more stringent professional competence of accounting talents. Under this background, accounting graduates can not effectively and reasonably use various accounting knowledge to carry out financial work; and accountants with working experience are extremely scarce, unable to meet the actual needs of society. 
With the sustainable development of supply-side reform, in order to promote the sustainable development of social economy, we must reform the accounting profession to provide high-quality professionals for the development of society. From the perspective of supply side, accounting profession is also facing more serious challenges. In order to promote social progress and meet the actual needs of society, it is necessary to reform and improve the accounting profession. In the initial stage of accounting system, the accounting major should thoroughly study the requirements of the supply side, synthesize the actual situation of accounting major, pay attention to the reform and reorganization of teaching materials, and formulate a perfect and scientific teaching mode based on the actual situation. Only in this way can the chivalrous delivery promote the sustainable development of accounting major.

\subsection{Challenges for accounting specialty from the perspective of supply side}

Under the background of supply side, it directly affects the depth and dimension of accounting information, expands the boundaries of accounting, pays more attention to the development of financial accounting, and pays more attention to financial accounting and management accounting under the background of supply side. At the same time, the supply side pays more attention to the efficiency and cost of accounting information. In the continuous development of network technology, big data and Internet of Things, it also effectively improves the accuracy and timeliness of accounting information, and fundamentally reduces the cost of accounting information. The supply side directly affects the efficiency of accounting information utilization.While providing accounting information, the providers of accounting information should fully analyze the utilization of accounting information. Only by highlighting the value and role of accounting information, can the utilization efficiency of information be improved. In practice, we should not only solve various problems through accounting information, but also highlight the problem of accounting information to solve trust. The effective use of accounting information can provide more perfect information value-added services.

\section{Analysis of Accounting Employment Prospect from the Perspective of Supply-side Reform}

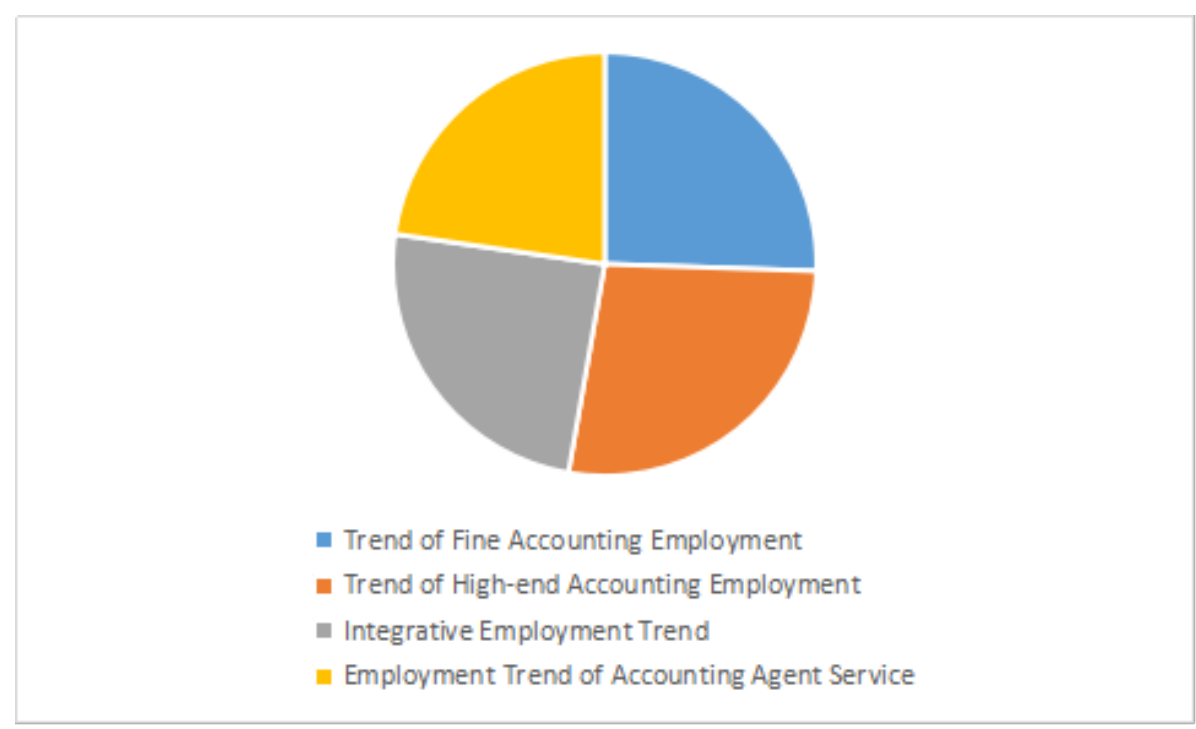

Figure 1.Analysis of Accounting Employment Prospect from the Perspective of Supply-side Reform As shown in figure 1, a detailed analysis is presented below. 


\subsection{Trend of fine accounting employment from the perspective of supply-side reform}

In the process of sustainable development of social economy, accounting boundary is expanding constantly. Accounting employment will also show professional development. In the future employment, "accounting + external reporting", "accounting + International trade", "accounting + taxation" and so on have a professional trend, will promote the development of the accounting industry, accounting employment in the future will present a refined trend.

\subsection{Trend of high-end accounting employment from the perspective of supply-side reform}

In the future development of accounting profession, the division of trade unions in accounting profession shows a trend of high-end, and a more significant trend of polarization. The basic work of financial accounting is accounting. With the continuous development of network technology, the accounting method of replacing manual work by computer has gradually developed. In this environment, some simple accounting work can be accomplished by computer, and the accounting profession is also affected by the perspective of supply-side reform. Domestic enterprises have a relatively large demand for accounting talents, which is also the main employment direction of accounting professionals at this stage.There is also room for improvement in their financial supervision and control systems. From the perspective of supply-side reform, if we want to promote the development of accounting profession, we need to improve the financial supervision and control system of internal enterprises. And the demand for domestic enterprises can be met by some secondary school graduates. With the promotion of standardization of accounting posts, some high-end managerial accountants are the main development trend.

\subsection{Integrative employment trend from the perspective of supply-side reform}

The so-called integration is in the "Internet + technology" background, through the network technology means, the business process, financial accounting management, management process of the system integration, to build a complete and systematic business event based integrated information processing flow, the financial data and business integration effectively, to achieve the sharing of financial information data. And the effective control of economic business, thereby highlighting the function of accounting control.

\subsection{Employment trend of accounting agent service from the perspective of supply-side reform}

The so-called accounting agency service industry is the development trend of standardization, industrialization and free accounting. Accounting service industry is a service industry that provides professional agent bookkeeping, agent taxation, financial consultation, auditing and other related services for enterprises. Accounting service institutions provide information content for enterprises, reform ideas of supply-side structure for enterprises, change traditional concepts, effectively integrate network technology means with industry, and then enhance their overall service capacity and level, so as to provide more high-end, professional and comprehensive professional services for social and economic development.

\section{Countermeasure and Suggestion of Accounting Education Transition Development under the Background of Supply-side Reform}

In the context of the current supply-side structural reform, the transformation and development of accounting education has become urgent. On October 27, 2014, the Ministry of Finance of China 
promulgated the Guiding Opinions on Promoting the Construction of Management Accounting System in an All-round Way. The guiding opinions point out that it is urgent for enterprises to enhance their value creativity. In the opinions, it is clearly put forward that the construction of management accounting talents should be based on the establishment of a management accounting system suitable for the socialist market economic system of our country, the construction of a Financial Sharing Center for enterprises, the expansion of accounting functions from accounting to management decision-making should be accelerated, the construction of management accounting curriculum system in Colleges and universities should be promoted, and the ways of training management accounting talents should be explored so as to realize the orientation of accounting talents. Management accounting talent transformation. As shown in Table 2:

Table 2. Countermeasure and Suggestion of Accounting Education Transition Development under the Background of Supply-side Reform

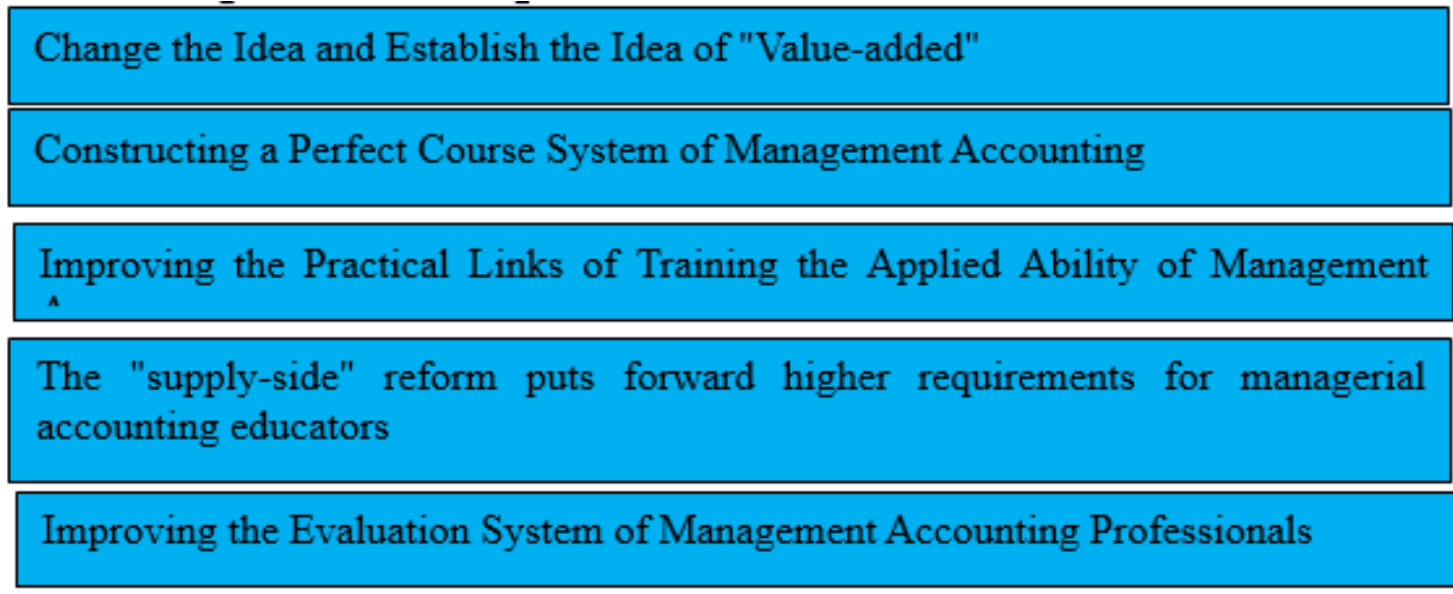

\subsection{Change the idea and establish the idea of "value-added"}

Accounting is the necessary accounting and Reflection Based on the needs of management, and its basic function is management. Therefore, under the "supply-side" reform, management accounting education is a new type of development to innovate the management function of comprehensive accounting. Accounting talents should establish the concept of "value-added", embedding accounting functions in the front-end business of enterprises and innovating management.

\subsection{Constructing a perfect course system of management accounting}

On June 22, 2016, the Ministry of Finance promulgated the Basic Guidelines for Management Accounting (No. 10, 2016). This guideline defines four elements of management accounting application, including application environment, management accounting activities, tools and methods, information and reports. Under the "supply side" reform, management accounting education is market-oriented, starting from the supply side, optimizing the demand side. Therefore, the construction of a sound management accounting curriculum system is based on the basic guidelines of management accounting to build two modular curriculum system.

\subsection{Improving the practical links of training the applied ability of management accounting}

The core of cultivating the applied ability of management accounting is to cultivate the 
innovative ability, break through the thinking pattern, learn to think logically, question and think flexibly. Therefore, the practical links of training the applied ability of management accounting are different from the contents and forms of financial accounting training. Construct a progressive three-module practical teaching system of management accounting.

\subsection{The "supply-side" reform puts forward higher requirements for managerial accounting educators}

As the saying goes, "A good teacher makes a good apprentice". Teachers and students are also a typical relationship between supply and demand. As the supply side, teachers still need structural reform, such as structural reform of knowledge, structural reform of teaching methods, structural reform of teaching mode innovation, etc. Starting from the supply side, we not only have solid theoretical knowledge, rich practical experience in management accounting, but also have innovative educational ideas and teaching methods, so as to promote teachers"'dual-ability" level, so as to optimize the demand side.

\section{Conclusion}

At the same time, the structural reform of supply side promotes the transformation and development of accounting talents to management accounting talents. At the same time, management accounting talents help supply side realize the reform goal of "three go, one fall and one subsidy". Similarly, the supply-side structural reform promotes the transformation of accounting education to management accounting education. At the same time, the transformation and development of accounting education in Colleges and universities optimizes the demand side from the supply side, provides high-quality labor force for the accounting talent market and promotes the improvement of total factor productivity of supply-side reform.

\section{References}

[1] Chaos Unique. Impact of Supply-side Structural Reform on Accounting Industry [J]. China Market, 2016 (29): 55-56.

[2] Ciao Juan. A Brief Talk on Accounting Function Exertion in Supply-side Structural Reform [J]. Scientific and Technological Innovation and Productivity, 2016 (6): 40-42.

[3] Yuan Anglia. Structural Reform of Higher Education from the Perspective of Supply Side [J]. Journal of National College of Educational Administration, 2016 (6): 15-21.

[4] Pan Managua, Chou Undying. Viewing the Construction of Applied Undergraduate Courses from the Perspective of University Classification [J]. Teaching in Chinese Universities, 2009 (3): 4-7.

[5] Lu Auxin. Shackles and Breakthroughs in the Connection between Higher Vocational Colleges and Applied Undergraduates [J]. Higher Education Research, 2012 (8): 59-60. 